\title{
Life cycles of Eukiefferiella claripennis (Lundbeck 1898) and Eukiefferiella minor (Edwards 1929) (Diptera: Chironomidae) in spring-fed streams of different temperatures with reference to climate change
}

\author{
Elisabet Ragna Hannesdóttir', Gisli Már Gislason' and Jón S. Ólatsson ${ }^{2}$
}

Hannesdóttir ER, Gíslason GM and Ólafsson JS. 2012. Life cycles of Eukiefferiella claripennis (Lundbeck 1898) and Eukiefferiella minor (Edwards 1929) (Diptera: Chironomidae) in spring-fed streams of different temperatures with reference to climate change. Fauna norvegica 31: 35-46.

The effect of temperature on the life cycles of two chironomid species, Eukiefferiella claripennis and Eukiefferiella minor, was studied by comparing populations from seven spring-fed streams, ranging in annual average temperatures between $5.4^{\circ} \mathrm{C}$ and $21.3^{\circ} \mathrm{C}$. Dependent on stream, both species showed differences in their life cycles: E. claripennis was regarded univoltine in the two coldest streams, IS7 (annual average $5.4^{\circ} \mathrm{C}$ ) and IS11 $\left(5.3^{\circ} \mathrm{C}\right.$ ), and bivoltine or multivoltine in the warmer streams (ranging from $9.7^{\circ} \mathrm{C}$ to $21.3^{\circ} \mathrm{C}$ ). E. claripennis developed and grew slower in the colder streams compared to the warmer ones. The winter generation in the warmer streams took longer time to complete compared to the summer generation. E. minor was bivoltine in all the streams, with no emergence during the winter in the colder streams, but in one of the warmer streams (IS6, $13.3^{\circ} \mathrm{C}$ ) emergence was continuous throughout the year. In four streams (IS7, cold; IS6, IS5 and IS1, warm) E. minor may even have been multivoltine. There was no trend between the number of generations completed in one year and stream temperature for $E$. minor. The summer generation of $E$. minor in the cold stream IS7 produced smaller larvae compared to the winter generation. Following global warming the life cycle of $E$. claripennis is expected to change from univoltine to bivoltine, and could show changes in emergence pattern. $E$. minor on the other hand, will likely show less change in its life cycle. Changes in emergence pattern of E. minor could though be possible.

doi: 10.5324/fn.v31i0.1367. Received: 2011-10-12. Accepted: 2012-05-15.

Published on paper and online: 2012-10-17.

Keywords: Geothermal area, spring-fed streams, Eukiefferiella claripennis, Eukiefferiella minor, life cycles

1. Institute of Life- and Environmental Sciences, Askja, Sturlugata 7, 101 Reykjavík, Iceland

2. Institute of Freshwater Fisheries, Keldnaholt, 112 Reykjavik, Iceland

Corresponding author: Elisabet Ragna Hannesdóttir

E-mail:erh@hi.is

\section{INTRODUCTION}

Global average surface warming is projected to be between $0.6^{\circ} \mathrm{C}$ and $4.0^{\circ} \mathrm{C}$ at the end of the 21 st century compared to 1980-1999 (Solomon et al. 2007). In the Arctic, the projected annual warming is $5^{\circ} \mathrm{C}$ by the end of the 21st century, estimated by the MMD-A1B ensemble mean projection (Christensen et al. 2007). The models range from $2.8^{\circ} \mathrm{C}$ to $7.8^{\circ} \mathrm{C}$ (Christensen et al.
2007). The greatest warming is expected in winter in the Arctic (ACIA 2004, Christensen et al. 2007, Solomon et al. 2007). By the end of the 21st century the average winter warming ranges from $4.3^{\circ} \mathrm{C}$ to $11.4^{\circ} \mathrm{C}$, and from $1.2^{\circ} \mathrm{C}$ to $5.3^{\circ} \mathrm{C}$ in summer under the A1B scenario (Christensen et al. 2007). Precipitation is also predicted to increase over the Arctic at the end of the 21st century (Christensen et al. 2007). Changes in the biota 
related to climate change are already occurring in the Arctic (CAFF 2010) and in Iceland the effect of climate change on the biota has been significant, with observed changes in vegetation (Wöll 2008), bird populations (Gunnarsson 2009, D’Alba et al. 2010), fish populations (Jónsson et al. 2001, Antonsson \& Gudbergsson 2006, Malmquist et al. 2009, Stefansdottir et al. 2010) and invertebrates (Gunnarsson \& Ásgeirsson 2006, Thórarinsdóttir et al. 2007, Libungan et al. 2009).

It is important to consider the temperature tolerance when determining species response to increased temperature (Walshe 1948). Species with a narrow temperature tolerance can be expected to either disappear, move to higher latitudes or higher elevations following global warming. For eurythermal species, changes in life history traits can be expected. Growth, development and timing of emergence are some of the lifehistory components that are affected by temperature (Sweeney 1984, Tokeshi 1995). Developmental rate increases with temperature up to a maximum (at optimum temperature) from which the developmental rate declines (Taylor 1981). The same is true for growth rates (Reynolds \& Benke 2005). Species that grow at higher temperatures (which do not exceed their optimum temperature) are therefore able to complete their life cycle in a shorter time (Oliver 1971), as long as other factors are not limiting. They may then be able to complete more generations per year. Such phenological changes (i.e. changes in voltinism) may be an indicator of species response to climate warming (Menzel et al. 2006, CAFF 2010). Studies have shown changes in the phenology of plants, arthropods and birds as a response to climate change, with an advance in flowering dates, arthropod emergence and clutch initiation dates (Stenström \& Jónsdóttir 2006, Høye et al. 2007). The number of studies on phenological changes related to climate change is limited in the Arctic (CAFF 2010), even though the Arctic is predicted to have the most rapid and dramatic biological response to climate change (Høye et al. 2007). In general more life-history research is needed (Resh \& Rosenberg 2010).

The aim of this study was to examine the effect of temperature on the life cycles of two eurythermal (Wiederholm 1983) chironomid species, Eukiefferiella claripennis (Lundbeck 1898) and Eukiefferiella minor (Edwards 1929). Spring-fed streams in the geothermal area of Hengill in south-west Iceland, which differed in temperature, were used for the present study. The null hypothesis was that there would be no difference in the number of generations completed in one year by $E$. claripennis and E. minor in streams differing in temperature. The alternative hypothesis was that the same species living under different temperature conditions would differ in the number of generation completed in one year. Individuals of the same species would complete more generations in the warmer than in the colder streams. Chironomids in the Arctic have life cycles that take one year or longer to complete (Oliver 1968). A study in Alaska tundra ponds has even demonstrated that it can take chironomids 7 years to complete their life cycle (Butler 1982). In the temperate region they are usually uni- or

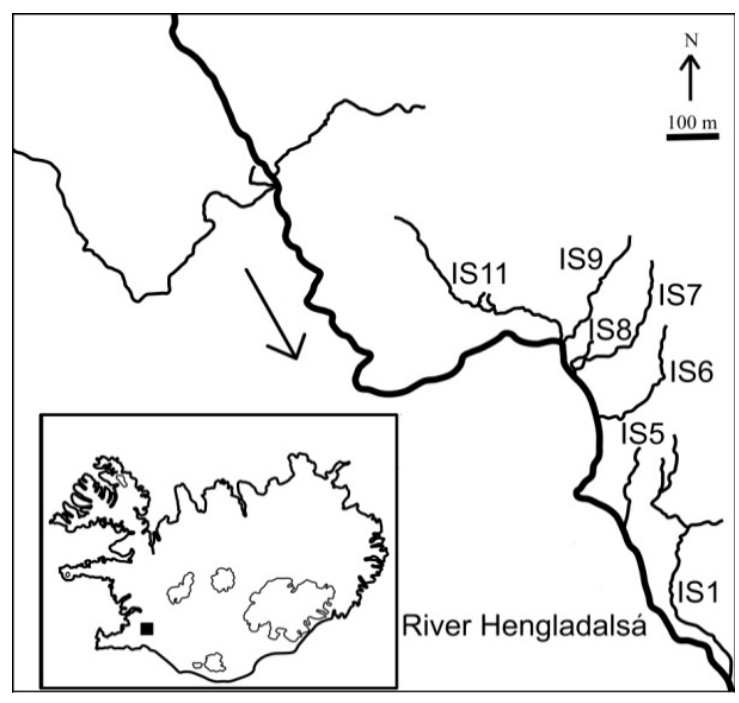

Figure I. Map showing the location of the research site, Hengill, in Iceland (black square) along with a drawing of the seven streams sampled. All of the streams run into the River Hengladalsá (with arrow indicating the direction of flow). Scale bar $100 \mathrm{~m}$. Drawing was based on aerial photographs with permission from Samsýn ehf.

bivoltine, but completion of three to four generations per year also occurs (Pinder 1986). Laboratory experiments have shown the effect of temperature on life cycles (Becker 1973, Mackey 1977, Brittain 1978, Al-Habbib \& Grainger 1981, Elliott 1987, Galka \& Brust 1987, Gíslason 1992, Frouz et al. 2002, Reynolds \& Benke 2005), but fewer studies have looked at life cycles at different temperatures in a natural setting (Lam \& Calow 1989, Gíslason 1992, Nolte \& Hoffmann 1992, Hodkinson et al. 1996, Ingólfsson et al. 2007) as we do in this study.

The streams in Hengill are an ideal model system because they provide a relevant temperature gradient that is largely unconfounded by other physicochemical variables (Friberg et al. 2009). Studies have shown that the invertebrate community in the streams in Hengill was dominated by chironomids, with E. minor comprising up to $50 \%$ of the individuals in the colder streams. E. claripennis was also common in all the streams (Christensen 2006, Friberg et al. 2009, Ólafsson et al. 2010, Woodward et al. 2010). The streams were species-poor with only 35 taxa recorded, but with the present taxa differing widely in their temperature tolerance (Woodward et al. 2010). E. minor and $E$. claripennis showed a wide temperature tolerance, being recorded in all of the streams in Hengill (Friberg et al. 2009, Ólafsson et al. 2010). In Iceland the two species are abundant and have been recorded from run-off and spring-fed streams and rivers (Hrafnsdottir 2005). E. minor has also been reported from glacial streams and in lakes (Hrafnsdottir 2005). 


\section{MATERIAL AND METHODS}

\section{Research site}

The research site was located in the Hengladalir valleys within the Mt. Hengill area, $30 \mathrm{~km}$ east of Reykjavík $\left(64^{\circ} 03^{\circ} \mathrm{N}\right.$ : $021^{\circ} 18^{\circ} \mathrm{W}, 350-420 \mathrm{~m}$ a.s.1.). Seven streams, ranging in summer temperature from $7.7^{\circ} \mathrm{C}$ to $23.5^{\circ} \mathrm{C}$ (Friberg et al. 2009), were selected for the present study (Figure 1). Hengill is a high temperature geothermal area (temperature over $200^{\circ} \mathrm{C}$ at $1 \mathrm{~km}$ depth) in the active volcanic zone, and has about 50 groups of hot springs distributed over an area of $50 \mathrm{~km}^{2}$ (Árnason et al. 1967). Moss- and grassland predominates in the Hengill area. Wetlands dominate the Middalur valley where most of the streams are located. Along the River Hengladalsá vast continuous grassland can be found (Gudjónsson et al. 2005). The streams were all in close proximity to one and other $(5-2000 \mathrm{~m})$ (Friberg et al. 2009), all running into the River Hengladalsá. All of the streams were spring-fed, either with (IS1, IS5, IS6 and IS8) or without (IS7, IS9 and IS11) geothermal influence (Friberg et al. 2009), and forming a temperature gradient. Despite the geothermal influence all the streams were comparable in water chemistry (Rasmussen et al. 2011).

\section{Field and laboratory methods}

Temperature data loggers (Tidbit, Onset 32K StowAway, USA) were placed in each stream at the beginning of the sampling period, recording water temperature every 30 minutes. Average temperature and standard deviation was calculated for each month for a period of one year, from September 2006 to August 2007. Winter (December, January and February) and summer (June, July and August) averages were also calculated.

The invertebrates were collected with a Surber sampler (KC mini Surber samples) with a frame size of $14 \times 14 \mathrm{~cm}$ and a $200 \mu \mathrm{m}$ mesh net. Samples were taken at random coordinates from the stream bed. Five samples were taken during each month of sampling per stream. In two streams (IS6 and IS7) samples were collected for 1.5 years (March 2006 to August 2007), but for the remaining five over a one year period (September 2006 to August 2007). Samples were collected monthly during the summer, and every second month during the winter. The samples were preserved in $70 \%$ ethanol until sorted. Macroinvertebrates were sorted and identified under a dissecting microscope to generic or species level. For each sample, a subsample of approximately one hundred chironomid larvae were mounted on a microscopic slide in Hoyer's medium (Anderson 1954). A maximum of 500 larvae was accordingly identified from each stream for each month of sampling. If the number of larvae was less than 100 in a sample, all were mounted and identified. The larval head widths (HW) were measured with $0.01 \mathrm{~mm}$ accuracy using a graticule ocular in the microscope (100 x magnification) before mounting, to be able to differentiate the instars (McCauley 1974). The body length of larvae was measured with $0.5 \mathrm{~mm}$ accuracy before mounting. The larvae were identified under a high power microscope and notes made on the presence of first instar larvae and prepupae (based on presence of wing disks). Keys used for larval identifications include Cranston (1982), Wiederholm (1983) and Schmid (1993). Chironomid pupae and pupal exuviae were identified to the lowest taxonomic level (genera/species) under a dissecting microscope using the keys by Wiederholm (1986), Langton (1991) and Wilson \& Ruse (2005).

For comparison of the life cycles of chironomids, focus was placed on two eurythermal species $E$. minor and $E$. claripennis. They were found in all of the streams and were abundant (Friberg et al. 2009, Woodward et al. 2010). Frequency histograms of the head widths were drawn to identify the instars for each species, with each peak representing an instar (Daly 1985). The average head width, standard deviation and range were calculated for each instar for both species in each stream. Based on rearing, first instar larvae could be determined by morphological features (such as shape of mentum). Spearman's rank order correlation was performed to see if there was a correlation between the proportions of each instar (separately) of $E$. claripennis for all the months sampled between a warm (IS6; $\left.13.3^{\circ} \mathrm{C}\right)$ and a cold $\left(\right.$ IS7; $\left.5.4^{\circ} \mathrm{C}\right)$ stream. The average body length of $E$. claripennis larvae from the same two streams was calculated for each month for growth comparisons. A Wilcoxon's test was performed to determine if there was a significant difference in the median body length of 4th instar E. minor larvae in different generations in the cold stream IS7 $\left(5.4^{\circ} \mathrm{C}\right)$. Statistics were done in SigmaStat version 3.1 and in the statistical software $\mathrm{R}$ version 2.9.0.

\section{RESULTS}

The streams differed in temperature, averaging from $5.3^{\circ} \mathrm{C}$ to $21.3^{\circ} \mathrm{C}$ (Figure 2, Table 1). Temperature fluctuations differed between streams, both on a monthly and annual basis. In streams IS7, IS5 and IS8 the water temperature was rather constant throughout the year compared to the other streams (Figure 2).

The distribution of the head capsule width enabled us to separate the larvae into four instars, with each peak in the frequency histogram representing an instar (Figure 3, Table 1). The range of head width increased with each instar.

\section{Life cycle of Eukiefferiella claripennis}

In the two coldest streams, IS7 (average annual temperature $5.4^{\circ} \mathrm{C}$ ) and IS11 (average annual temperature $5.3^{\circ} \mathrm{C}$ ), E. claripennis was univoltine, with emergence and appearance of a new generation during the summer (Figures 4 and 6). In stream IS7, first instar larvae appeared in June or July, followed by second instar larvae in August to December, third instar from February to April, and in May only 4th instar larvae were found. A new generation appeared in June 2007 overlapping with the remainder of the previous generation. Pupae and pupal exuviae were found during the summer. In stream IS11 
IS7

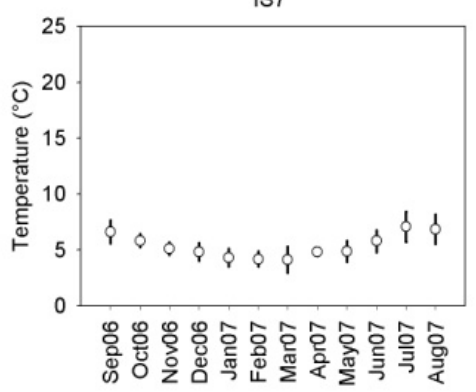

IS6

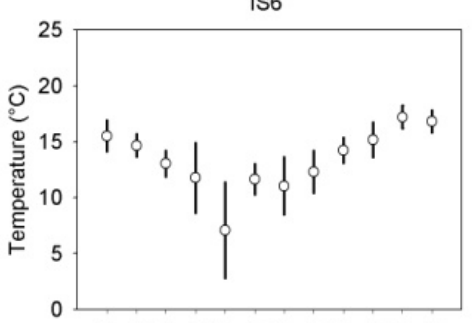

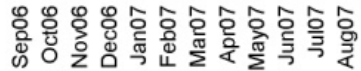

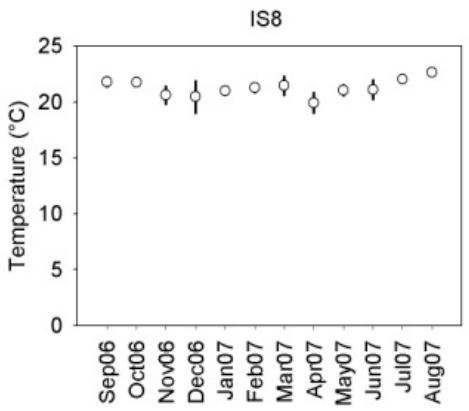

IS11

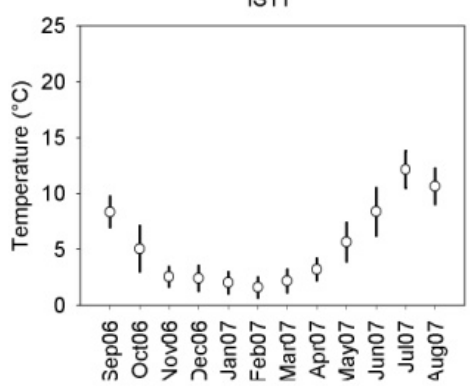

IS5

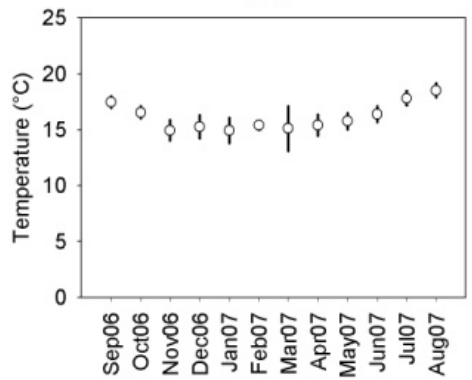

IS9
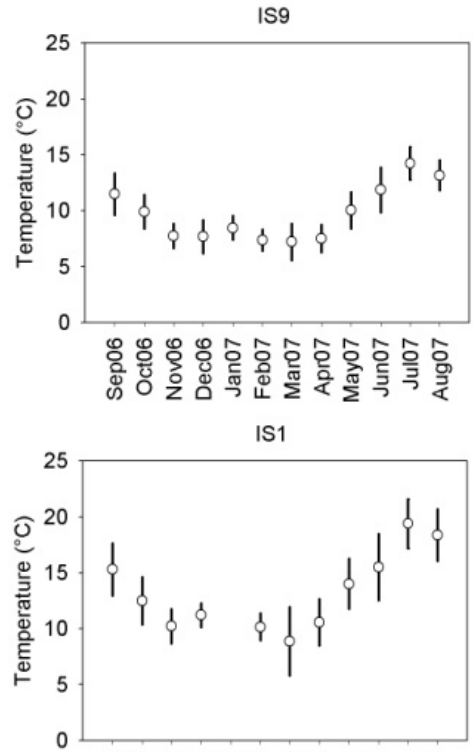

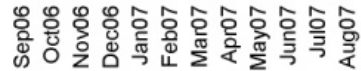

Figure 2. Stream water temperature $\left({ }^{\circ} \mathrm{C}\right)$, with average values and standard deviations for each month from September 2006 to August 2007. In stream IS1 the temperature logger was on dry land from December 10th to February 10th. Values were calculated from available data, from 1st-9th of December and 11th-28th of February, from stream IS1.
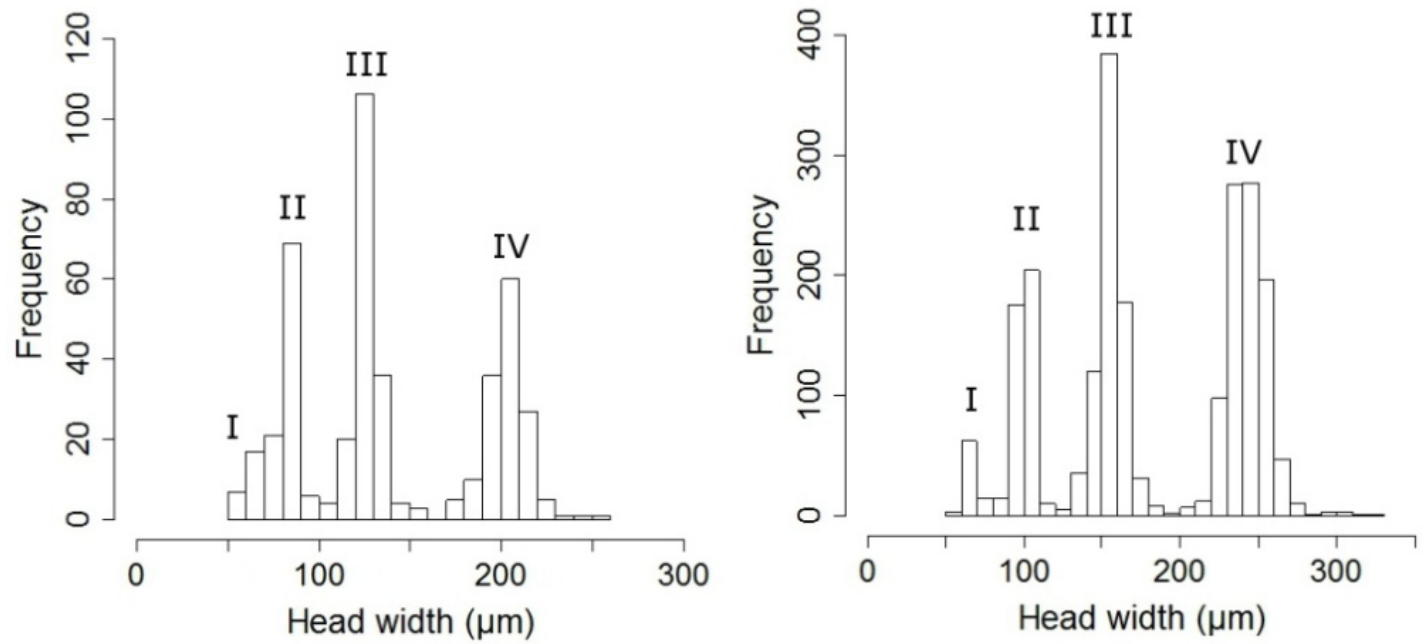

Figure 3. Frequency histograms of the head widths $(\mu \mathrm{m})$ of E. claripennis (left) and E. minor (right) from stream IS6. The instars are indicated (I-IV). Note the different scales on the y-axis. 
Table I. Head width $(\mu \mathrm{m})$ range, average, standard deviation and number of individuals measured $(\mathrm{n})$ for $E$. claripennis and $E$. minor for each instar (I to IV) in all the streams. Average annual water temperature $\left({ }^{\circ} \mathrm{C}\right)$ is included after the stream names.

\begin{tabular}{|c|c|c|c|c|c|c|c|c|}
\hline & \multicolumn{4}{|c|}{ Eukiefferiella claripennis } & \multicolumn{4}{|c|}{ Eukiefferiella minor } \\
\hline & I & II & III & IV & I & II & III & IV \\
\hline IS7 $\left(5.4^{\circ} \mathrm{C}\right)$ & $\begin{array}{c}51-61 \\
60 \pm 3 \\
(\mathrm{n}=10)\end{array}$ & $\begin{array}{c}71-91 \\
77 \pm 5 \\
(\mathrm{n}=171)\end{array}$ & $\begin{array}{c}101-152 \\
120 \pm 8 \\
(\mathrm{n}=80)\end{array}$ & $\begin{array}{c}192-233 \\
205 \pm 9 \\
(\mathrm{n}=24)\end{array}$ & $\begin{array}{c}51-71 \\
63 \pm 5 \\
(\mathrm{n}=146)\end{array}$ & $\begin{array}{c}81-111 \\
93 \pm 7 \\
(\mathrm{n}=719)\end{array}$ & $\begin{array}{c}122-172 \\
147 \pm 11 \\
(n=408)\end{array}$ & $\begin{array}{l}192-304 \\
239 \pm 14 \\
(\mathrm{n}=720)\end{array}$ \\
\hline IS11 $\left(5.3^{\circ} \mathrm{C}\right)$ & $\begin{array}{c}51-61 \\
56 \pm 5 \\
(\mathrm{n}=21)\end{array}$ & $\begin{array}{c}71-91 \\
78 \pm 6 \\
(\mathrm{n}=239)\end{array}$ & $\begin{array}{c}101-152 \\
122 \pm 8 \\
(\mathrm{n}=99)\end{array}$ & $\begin{array}{c}172-213 \\
196 \pm 17 \\
(\mathrm{n}=12)\end{array}$ & $\begin{array}{c}51-71 \\
62 \pm 6 \\
(\mathrm{n}=53)\end{array}$ & $\begin{array}{c}81-111 \\
94 \pm 7 \\
(\mathrm{n}=682)\end{array}$ & $\begin{array}{c}122-182 \\
149 \pm 10 \\
(\mathrm{n}=472)\end{array}$ & $\begin{array}{c}203-273 \\
241 \pm 14 \\
(\mathrm{n}=321)\end{array}$ \\
\hline IS9 $\left(9.7^{\circ} \mathrm{C}\right)$ & $\begin{array}{c}51-61 \\
55 \pm 5 \\
(\mathrm{n}=19)\end{array}$ & $\begin{array}{c}71-91 \\
76 \pm 6 \\
(\mathrm{n}=56)\end{array}$ & $\begin{array}{c}101-132 \\
120 \pm 7 \\
(\mathrm{n}=57)\end{array}$ & $\begin{array}{c}152-223 \\
190 \pm 15 \\
(\mathrm{n}=36)\end{array}$ & $\begin{array}{c}51-71 \\
60 \pm 5 \\
(n=45)\end{array}$ & $\begin{array}{c}81-111 \\
96 \pm 7 \\
(n=283)\end{array}$ & $\begin{array}{c}122-182 \\
153 \pm 10 \\
(n=244)\end{array}$ & $\begin{array}{l}192-294 \\
243 \pm 15 \\
(\mathrm{n}=189)\end{array}$ \\
\hline IS6 $\left(13.3^{\circ} \mathrm{C}\right)$ & $\begin{array}{c}51-61 \\
58 \pm 5 \\
(n=24)\end{array}$ & $\begin{array}{c}71-91 \\
79 \pm 5 \\
(n=96)\end{array}$ & $\begin{array}{c}101-152 \\
123 \pm 8 \\
(n=173)\end{array}$ & $\begin{array}{l}172-253 \\
201 \pm 12 \\
(\mathrm{n}=146)\end{array}$ & $\begin{array}{c}51-71 \\
62 \pm 5 \\
(\mathrm{n}=81)\end{array}$ & $\begin{array}{c}81-111 \\
96 \pm 6 \\
(n=405)\end{array}$ & $\begin{array}{c}122-182 \\
153 \pm 10 \\
(\mathrm{n}=762)\end{array}$ & $\begin{array}{l}192-324 \\
241 \pm 14 \\
(\mathrm{n}=937)\end{array}$ \\
\hline IS5 $\left(16.1^{\circ} \mathrm{C}\right)$ & $\begin{array}{c}51-61 \\
56 \pm 5 \\
(n=29)\end{array}$ & $\begin{array}{c}71-91 \\
76 \pm 6 \\
(n=197)\end{array}$ & $\begin{array}{c}101-142 \\
121 \pm 7 \\
(n=160)\end{array}$ & $\begin{array}{c}162-223 \\
195 \pm 12 \\
(n=119)\end{array}$ & $\begin{array}{c}61-71 \\
65 \pm 5 \\
(n=39)\end{array}$ & $\begin{array}{c}81-111 \\
93 \pm 7 \\
(\mathrm{n}=271)\end{array}$ & $\begin{array}{c}122-172 \\
149 \pm 12 \\
(\mathrm{n}=185)\end{array}$ & $\begin{array}{l}203-273 \\
244 \pm 14 \\
(\mathrm{n}=294)\end{array}$ \\
\hline IS1 $\left(13.5^{\circ} \mathrm{C}\right)$ & $\begin{array}{l}51-61 \\
57 \pm 6 \\
(\mathrm{n}=3)\end{array}$ & $\begin{array}{c}71-91 \\
76 \pm 6 \\
(\mathrm{n}=76)\end{array}$ & $\begin{array}{c}101-142 \\
117 \pm 7 \\
(\mathrm{n}=117)\end{array}$ & $\begin{array}{c}152-233 \\
188 \pm 16 \\
(\mathrm{n}=188)\end{array}$ & $\begin{array}{l}51-71 \\
61 \pm 6 \\
(\mathrm{n}=6)\end{array}$ & $\begin{array}{c}81-111 \\
93 \pm 6 \\
(\mathrm{n}=95)\end{array}$ & $\begin{array}{l}122-171 \\
146 \pm 12 \\
(\mathrm{n}=123)\end{array}$ & $\begin{array}{c}213-273 \\
238 \pm 15 \\
(\mathrm{n}=98)\end{array}$ \\
\hline IS8 $\left(21.3^{\circ} \mathrm{C}\right)$ & $\begin{array}{c}51-61 \\
58 \pm 5 \\
(\mathrm{n}=31)\end{array}$ & $\begin{array}{c}71-91 \\
81 \pm 6 \\
(\mathrm{n}=175)\end{array}$ & $\begin{array}{c}101-152 \\
128 \pm 8 \\
(\mathrm{n}=381)\end{array}$ & $\begin{array}{l}162-233 \\
200 \pm 12 \\
(\mathrm{n}=225)\end{array}$ & $\begin{array}{c}51-71 \\
63 \pm 5 \\
(\mathrm{n}=24)\end{array}$ & $\begin{array}{c}81-122 \\
99 \pm 8 \\
(\mathrm{n}=120)\end{array}$ & $\begin{array}{c}132-182 \\
153 \pm 10 \\
(\mathrm{n}=94)\end{array}$ & $\begin{array}{c}213-273 \\
240 \pm 15 \\
(\mathrm{n}=71)\end{array}$ \\
\hline
\end{tabular}

E. claripennis showed a similar pattern in life cycle as it did in stream IS7. Fourth instar larvae appeared earlier in stream IS7 (March and April 2007), compared to in June 2007 in stream IS11. E. claripennis in IS9 (average annual temperature $9.7^{\circ} \mathrm{C}$ ) had a long winter generation, extending from late summer to late spring and a short summer generation, lasting only a few months. The larvae of the winter generation grew faster in this stream compared to the larvae in streams IS7 and IS11. In stream IS6 (average annual temperature $13.3^{\circ} \mathrm{C}$ ) a similar life cycle pattern was seen as in IS9. In IS5 (average annual temperature $\left.16.1^{\circ} \mathrm{C}\right)$ E. claripennis had at least two generations per year, with a long winter generation extending from late summer to spring. From May to July larvae of all instars were present in different proportions implying the possibility of more than one summer generations. In IS1 (average annual temperature $\left.13.5^{\circ} \mathrm{C}\right)$ E. claripennis was bivoltine, with a similar life cycle pattern as in IS9 and IS6, although individuals of the winter generation seemed to grow faster compared to those found in IS9. In stream IS8 (average annual temperature $\left.21.3^{\circ} \mathrm{C}\right)$ E. claripennis larvae were absent from the stream from February to May 2007 making life cycle analysis difficult. Spearman's rank order correlation on the proportion of each instar between streams IS6 and IS7 revealed a non-significant correlation $(P>0.05)$ between all the instars expect the first
$(P=0.031)$, indicating that the larvae had a different life cycle in the two streams. Comparison of the growth of the larvae in streams IS7 and IS6 (Figure 5), showed that the larvae of the winter generation grew faster in the warmer stream IS6 than the larvae in IS7. E. claripennis showed a difference in the number of generations completed in one year between streams of different temperatures. We therefore reject the null hypothesis and accept the alternative hypothesis that $E$. claripennis can complete more generations per year in warmer than in colder streams.

Based on the presence of pupae and pupal exuviae, the emergence of E. claripennis occurred mostly during the summer, with highest abundance from May to September (in May accounting for $22.5 \%$, in July $25.0 \%$, August $12.5 \%$ and in September $27.5 \%$ of pupae and pupal exuviae found during the year). Only $10 \%$ of the pupae and pupal exuviae were found from December to April. In two of the warmer streams, IS5 $\left(16.1^{\circ} \mathrm{C}\right)$ and IS1 $\left(13.5^{\circ} \mathrm{C}\right)$, pupae and pupal exuviae were present during the winter, but in low numbers (Figure 6). These results indicate differences in the emergence pattern of E. claripennis related to temperature. In warmer streams individuals emerged both in winter and summer compared to only in summer in the colder streams. 


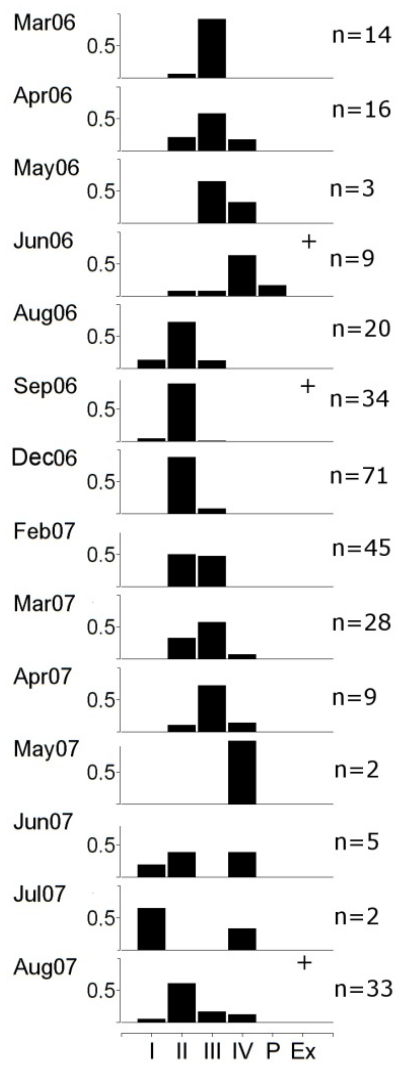

IS7

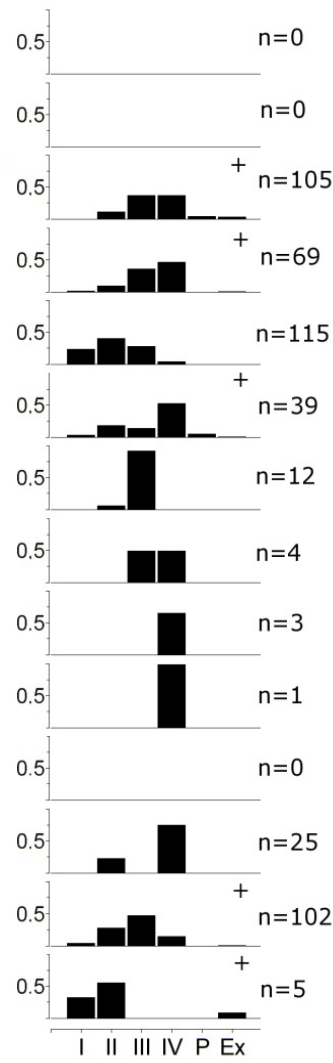

IS6
Figure 4. Life cycle of Eukiefferiella claripennis in streams IS7 (average temperature $5.4^{\circ} \mathrm{C}$ ) and IS6 (average temperature $13.3^{\circ} \mathrm{C}$ ). The four larval stages (instars) are shown with roman letters from I to IV, pupae are indicated with the letter $P$ and pupal exuviae with the letters Ex. The proportion of each life stage is expressed on the $y$-axis. + indicates the presence of pupae and/or pupal exuviae. The number of individuals (n) in each month is shown.
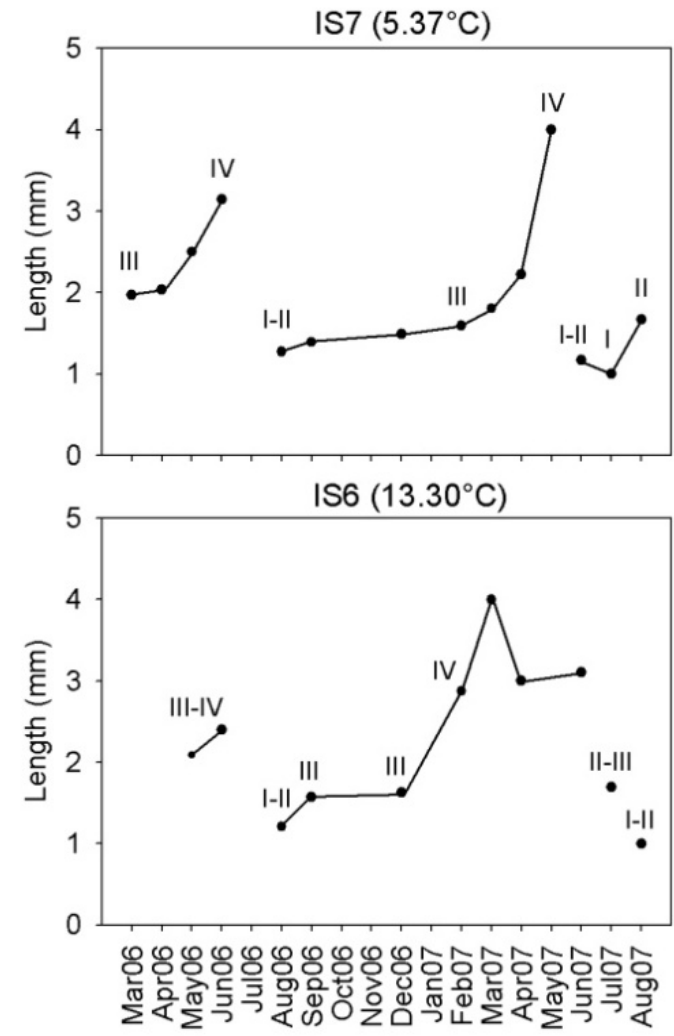

Figure 5. Average body length $(\mathrm{mm})$ of $E$. claripennis larvae in streams IS7 (average temperature $5.4^{\circ} \mathrm{C}$ ) and IS6 (average temperature $13.3^{\circ} \mathrm{C}$ ) for each month of sampling. The larval stages (I-IV) are shown.

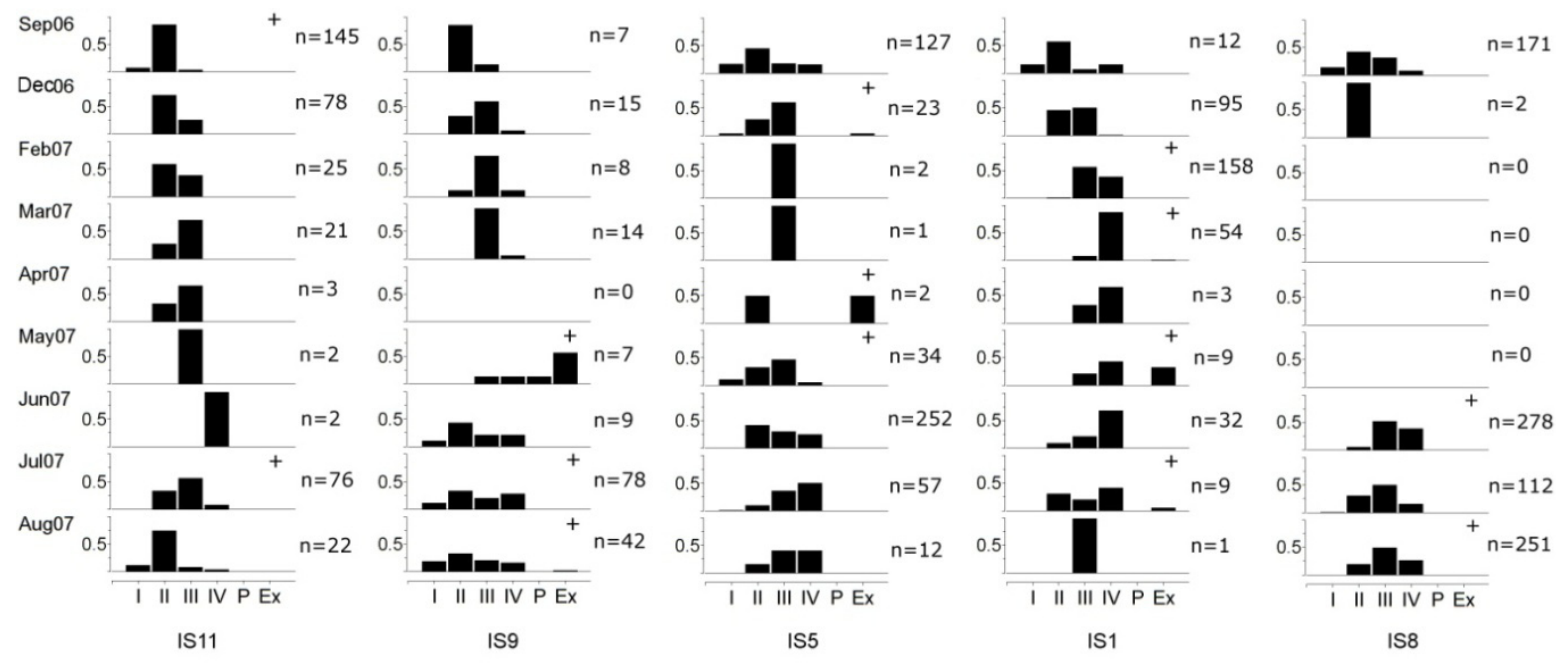

Figure 6. Life cycle of Eukiefferiella claripennis in streams IS11 (average temperature $\left.5.3^{\circ} \mathrm{C}\right)$, IS9 $\left(9.7^{\circ} \mathrm{C}\right)$, IS5 $\left(16.1^{\circ} \mathrm{C}\right)$, IS1 $\left(13.5^{\circ} \mathrm{C}\right)$ and IS8 $\left(21.3^{\circ} \mathrm{C}\right)$. See figure 4 for further explanation. 


\section{Life cycle of Eukiefferiella minor}

In stream IS7 (average annual temperature $5.4^{\circ} \mathrm{C}$ ) E. minor had at least two generations per year, with a long winter generation, extending from late summer to spring and shorter summer generations (Figure 7). There was a significant difference between the median length of 4th instar larvae between the winter and summer generations $(P<0.05$, Wilcoxon's test). The 4th instar larvae of the winter generations were larger than those of the summer generation (averaged $4.52 \mathrm{~mm}$ in May 2006 (winter generation) compared to $3.88 \mathrm{~mm}$ in August 2006 (summer generation)). In stream IS11 $\left(5.3^{\circ} \mathrm{C}\right)$ E. minor was bivoltine with a long winter generation and a short summer generation (Figure 8). Individuals of the winter generation grew slower in this stream compared to the larvae from stream IS7, with larvae reaching 4th instar mostly in May and June 2007, instead of April 2007 in stream IS7. In stream IS9 $\left(9.7^{\circ} \mathrm{C}\right), E$. minor was bivoltine with a similar life cycle pattern as in stream IS7. In stream IS6 $\left(13.3^{\circ} \mathrm{C}\right)$ E. minor had at least two generations per year. In most months individuals of all larval stages were found, differing in proportions between months. In stream IS5 $\left(16.1^{\circ} \mathrm{C}\right)$ E. minor had at least two generations per year. In stream IS1 $\left(13.5^{\circ} \mathrm{C}\right) E$. minor had two or more generations per year. In stream IS8 $\left(21.3^{\circ} \mathrm{C}\right) \mathrm{E}$. minor is assumed to have two generations per year, although more individuals would be needed in some months to confirm this. E. minor completed two generations per year in all streams but in some streams (IS7, IS6, IS5 and IS1) a multivoltine life cycle is a possibility. A more frequent sampling would have been needed to determine this. We therefore reject the null hypothesis but cannot accept the alternative one either, because the results indicate that in some streams $E$. minor might be multivoltine, while in the other bivoltine unrelated to temperature.

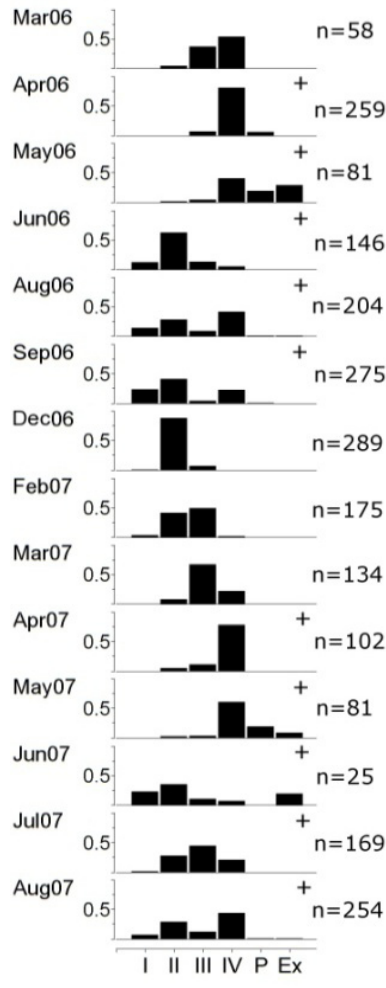

IS7

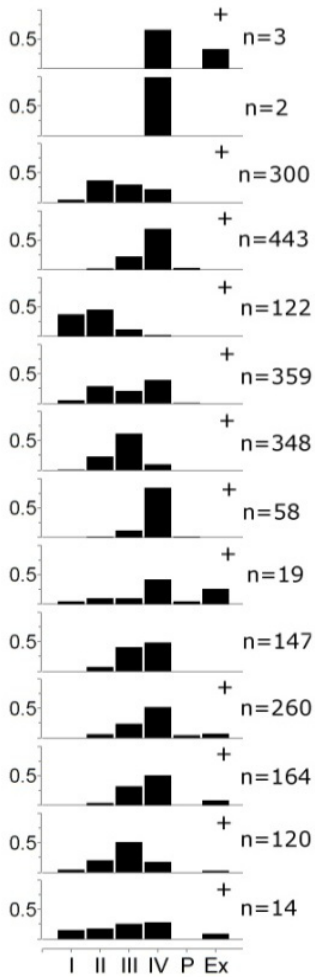

IS6
Figure 7. Life cycle of Eukiefferiella minor in streams IS7 (average temperature $\left.5.4^{\circ} \mathrm{C}\right)$ and IS6 $\left(13.3^{\circ} \mathrm{C}\right)$. See figure 4 for further explanation.

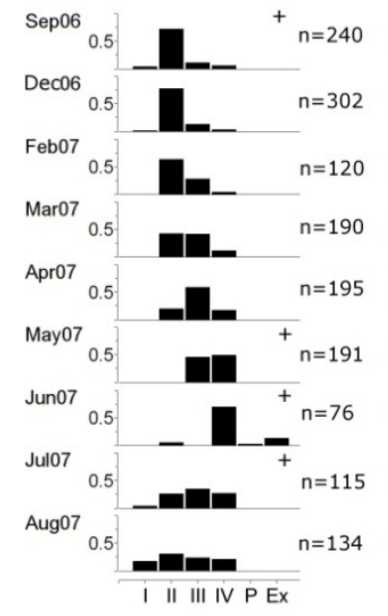

IS11

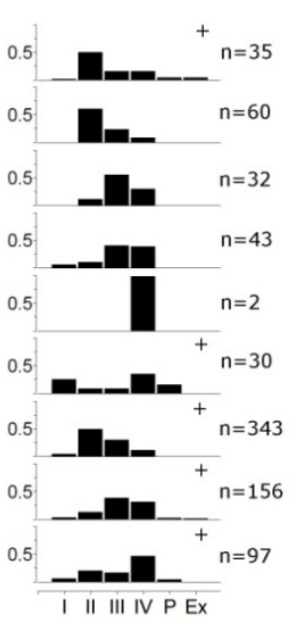

IS9

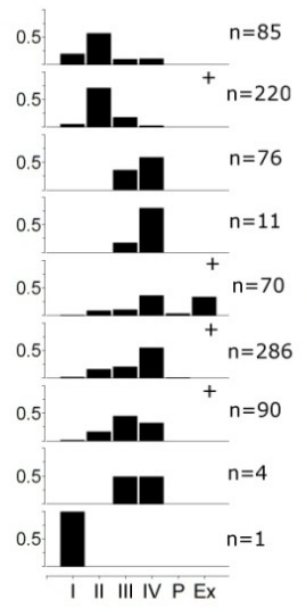

IS5

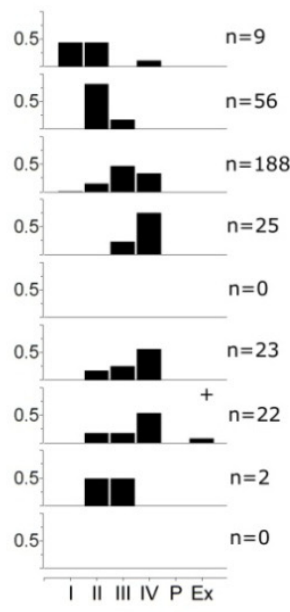

IS1

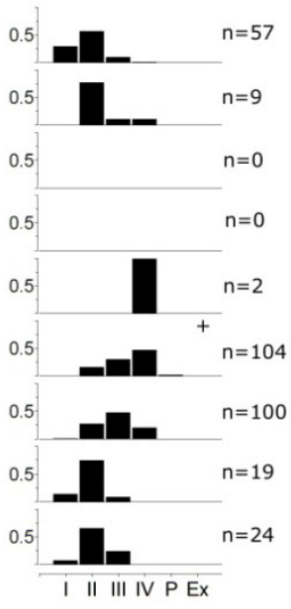

IS8

Figure 8. Life cycle of Eukiefferiella minor in streams IS11 (average temperature $\left.5.3^{\circ} \mathrm{C}\right)$, IS9 $\left(9.7^{\circ} \mathrm{C}\right)$, IS5 $\left(16.1^{\circ} \mathrm{C}\right)$, IS1 $\left(13.5^{\circ} \mathrm{C}\right)$ and IS8 $\left(21.3^{\circ} \mathrm{C}\right)$. See figure 4 for further explanation. 
Based on the presence of pupae and pupal exuviae, emergence of $E$. minor occurred mostly during the summer, with the highest abundance in May (accounting for $32.6 \%$ of pupae and pupal exuviae found during the year). The relative abundance of pupae and pupal exuviae were also high in June (12.1\%), August (16.1\%) and September (19.3\%). Only a small number was recorded from December to March (in total 3.7\%). In the warm stream, IS6 $\left(13.3^{\circ} \mathrm{C}\right)$, pupae and pupal exuviae were found throughout the year (Figure 7). In the other streams pupae and pupal exuviae were not found during winter (Figure 7 and 8).

\section{DISCUSSION}

E. claripennis larvae developed and grew slower in the colder streams compared to the larvae in the warmer streams. The species completed one generation per year in the colder streams, but was bivoltine in the warmer streams. There is a possibility that the species completed more than two generations per year in the warmer streams, with one winter generation and more than one summer generation. Resolving this issue can only be done with more frequent sampling during the summer. Differences in emergence pattern of E. claripennis were also seen, with winter and summer emergence in two of the warmer streams (IS5 and IS1), while in colder streams emergence was only in summer. Individuals that develop and grow fast need more energy and ingest more food than those that grow more slowly. A shortage of suitable food could therefore be a limiting factor, especially for the fast growing summer generation(s) in the warm streams. Chironomid larvae feed mainly on algae, detritus, and invertebrates, and some studies mention macrophytes and woody debris as a food source (Berg 1995). E. claripennis 4th instar larvae have been reported to feed preferentially on Chlorophyceae and Cyanophyceae, in a high nutrient enriched stream in France (Maasri et al. 2010).

During the summer epilithic algal (diatoms, green algae and Cyanobacteria) production differed between streams in Hengill, which could not be explained by temperature or other environmental variable (Gudmundsdottir et al. 2011). The algal community differed also between streams (Gudmundsdottir et al. 2011). E. claripennis, completing one generation per year in the two coldest streams, seemed to grow more rapidly in stream IS7 (annual average $5.4^{\circ} \mathrm{C}$ ) than in stream IS11 (annual average $5.3^{\circ} \mathrm{C}$ ). This could be due to more constant annual temperature, higher winter temperatures (Figure 2) and higher summer algal production (Gudmundsdottir et al. 2011) in stream IS7. In three warmer streams (IS9, IS6 and IS1), with high summer algal production like in the cold stream IS7 (Gudmundsdottir et al. 2011), E. claripennis was bivoltine. In the remaining two warmer streams (IS5 and IS8), where summer algal production was lower, like in the cold stream IS11 (Gudmundsdottir et al. 2011), E. claripennis was also bivoltine and possibly multivoltine in stream IS5 (average annual temperature $16.1^{\circ} \mathrm{C}$ ).
This indicates that temperature, not algal production, was the limiting factor for growth and development of E. claripennis in the streams in Hengill during the summer.

During the winter, when primary production decreased (R. Gudmundsdóttir, University of Iceland, Iceland, pers. comm.), and water temperatures were lower than in summer (Figure 2), conditions for the larvae were likely less favourable. In two of the warmest streams (IS5 and IS8), water temperatures were constant during the year, decreasing only slightly during winter (Figure 2). Here we might expect algal production to limit the growth and development of E. claripennis larvae during the winter, based on the fact that algal production was already low during summer (Gudmundsdottir et al. 2011). In the coldest stream (IS7), which had a rather stable water temperature throughout the year (Figure 2), both temperature and algal production might be limiting. For the other cold stream (IS11), which had large annual temperature fluctuations, temperature and algal production are likely limiting factors. For the remainder of the streams (IS9, IS6 and IS1), the annual temperature fluctuations were higher, so both algal production and temperature might be limiting during winter.

In the colder streams the cover of bryophytes and vascular plants was low, but in the warmer streams the bryophyte species Fontinalis antipyretica was abundant, with up to $80 \%$ cover (Gudmundsdottir et al. 2011). The study (Gudmundsdottir et al. 2011) did not look at epiphytic algae on bryophytes and macrophytes in the streams, which might contribute to the food supply for chironomid larvae, especially in the warmer streams.

This study indicates that during the summer temperature limits growth and development of E. claripennis. In winter, temperature and algal production are likely limiting in most streams, except in the warm streams IS5 and IS8, where algal production is likely limiting. A study by Gislason et al. (1995) in River Laxá, NE Iceland, showed a temporal and spatial variation in the number of flight periods (up to two) of $E$. claripennis, related to benthic primary production. Stefánsson (2005) also indicated a temporal variability in the voltinism of E. claripennis, in the surface flowing River Dælisá in SW Iceland. The study showed that $E$. claripennis was bivoltine with one generation appearing in July and a second one in October (Stefánsson 2005). Stefánsson (2005) predicted a univoltine life cycle during some years because of late emergence of the first generation.

E. minor had two generations per year in all the streams with a possibility of a multivoltine life cycle in four streams. In the colder streams, pupae and pupal exuviae were found from April to September, with highest numbers during spring and summer. From December to March no pupae or pupal exuviae were recorded in these streams. This pattern indicates that emergence was limited to the summer months, when stream temperatures (Figure 2) and epilithic algal production was higher (R. Gudmundsdóttir, University of Iceland, Iceland, pers. comm.). In the coldest stream IS7 the short summer 
generation produced significantly smaller larvae compared to the larvae from the longer winter generation. These results are in accordance with Oliver (1971), that noted that smaller individuals can be expected with increased temperature because development proceeds faster than growth. On the other hand, in the warm stream IS6 pupae and pupal exuviae were found in every month of sampling, except in April, with the highest abundances in May. These results indicate a continuous emergence throughout the year. This could be due to the higher water temperature in IS6, especially in winter (Figure 2). Epilithic algal production was high in both streams IS7 and IS6 during the summer, especially in stream IS7 (mostly Cyanobacteria) (Gudmundsdottir et al. 2011). In the winter the primary production was lower than in the summer (R. Gudmundsdóttir, University of Iceland, Iceland, pers. comm.). Differences in algal production and stream temperature in winter could possibly explain the different emergence patterns in streams IS6 and IS7. Larvae of the winter generation of E. minor grew slower in stream IS11 than in IS7, this could be due to more constant annual temperature, higher winter temperatures (Figure 2) and higher summer algal production (Gudmundsdottir et al. 2011) in stream IS7.

In River Dælisá, E. minor was reported to have at least two generations per year, with emergence from late April through late July (Stefánsson 2005). A study on the flight period of chironomids in River Laxá, NE Iceland, showed that E. minor was one of the most common species in all traps, and seemed to have two flight periods per year. Samples were collected from May to October 1978 (Jonsson et al. 1986, Gislason et al. 1995, Gardarsson et al. 2000), so knowledge on emergence during winter (the period from December to April) was lacking. A study on emergence of chironomids from Lake Mývatn and River Laxá, NE Iceland between, 1977 and 1992 indicated that E. minor had two flight periods per year (Gardarsson et al. 2000). A study conducted between 1975 and 1978 in the oligotrophic Lake Thingvallavatn, S Iceland, showed that E. minor was bivoltine, with a short summer generation (2-3 months) and a long winter generation (9-10 months) (Lindegaard 1992). These studies in Iceland indicate that $E$. minor is bivoltine at ambient temperatures in non-geothermal influenced streams. Results from the present study suggests that the timing of emergence of $E$. minor differs between streams of differing temperature, with a continuous emergence throughout the year in a warmer stream (IS6) compared to the colder streams, where emergence is limited to early summer to spring.

As the temperature rises in the Arctic the cold streams in Hengill will warm up, especially in winter as predicted (Christensen et al. 2007). We expect changes in the voltinism of E. claripennis by the end of the 21st century in the Arctic, from univoltine to bivoltine, following the projected warming $\left(1.2^{\circ} \mathrm{C}\right.$ to $5.3^{\circ} \mathrm{C}$ in summer and $4.3^{\circ} \mathrm{C}$ to $11.4^{\circ} \mathrm{C}$ in winter) (Christensen et al. 2007). An increase of $2.7^{\circ} \mathrm{C}$ in summer and $5.8^{\circ} \mathrm{C}$ in winter (difference between averages in streams IS9 and IS11) could cause these changes in the voltinism of $E$. claripennis. A further temperature rise, above the projected summer maximum (increase of $7.4{ }^{\circ} \mathrm{C}$ ), but within the winter projected range (increase of $8.5^{\circ} \mathrm{C}$, difference between streams IS1 and IS11), could result in changes in the emergence pattern of E. claripennis. Emergence might then occur not only during the summer, but also in winter. Changes in voltinism or emergence pattern are not expected to occur for $E$. minor by the end of the 21st century, following the projected warming in the Arctic (Christensen et al. 2007). In stream IS6 E. minor had a continuous emergence throughout the year. In the other streams the species did not emerge during winter. If the temperature would increase by $6.0^{\circ} \mathrm{C}$ on average in summer (difference between streams IS6 and IS11), then E. minor might emerge continuously throughout the year, as it does in stream IS6. This increase is just above the projected maximum of $5.3^{\circ} \mathrm{C}$ (Christensen et al. 2007), so changes in emergence of E. minor are unlikely to occur by the end of the 21st century.

Chironomids are important food for other animals, especially fish (Steingrímsson \& Gíslason 2002) and birds (Gardarsson 1979). Hatching of birds' eggs and fish roes is timed according to the availability of food and other resources, and changes in emergence of chironomids could possibly lead to a decline or even a collapse of the breeding populations. A study at Lake Mývatn showed that the production of the duck species Bucephala islandica was limited by the availability of aquatic insects, and that there was a strong relationship between chironomid abundance and spring numbers of ducks (Einarsson et al. 2006). The question remains whether phenological changes in chironomids and other aquatic taxa following global warming will have repercussions through the food-web. Phenological changes in predators of aquatic insects can be expected, following global warming, to match the changes in their prey.

\section{ACKNOWLEDGMENTS}

Gratitude to Árni Einarsson, Elizabeth Cook, Haukur Hauksson, Hlynur Bárdarsson, Kristinn Ó. Kristinsson, Nikolai Friberg, Ólafur P. Ólafsson, Ragnhildur Fridriksdóttir, Viktor B. Pálsson and many others too numerous to mention, for assistance in the field and/or laboratory. Our gratitude goes to Rakel Gudmundsdóttir for joint fieldwork and collaboration in the Eurolimpacs project. Thanks to staff and students of the Institute of Freshwater Fisheries and of the Institute of Life- and Environmental Sciences. Our appreciation goes to Professor Leonard C. Ferrington Jr. and The Chironomidae Research Group at the University of Minnesota. Thanks to Samsýn ehf for providing maps of the research area. The municipality of Ölfus is thanked for permitting research in the Hengill area. Research grants from the European Union (Eurolimpacs project GOCECT-2003-505540), the Icelandic Centre for Research (Icelandic Research Fund for Graduate Students no. 60230006), the University of Iceland Research Fund, the University of 
Iceland Assistantship Grant and the International Student Exchange Programs (ISEP) are gratefully acknowledged.

\section{REFERENCES}

ACIA. 2004. Impacts of a warming arctic: arctic climatic impact assessment. Cambridge University Press, available at: http:// www.acia.uaf.edu.

Al-Habbib OAM, Grainger JNR. 1981. The effect of changing temperatures on the development of the eggs of Lymnaea peregra (Müller). Journal of Thermal Biology 6(1): 35-36.

Anderson LE. 1954. Hoyer's solution as a rapid permanent mounting medium for bryophytes. The Bryologist 57: 242-243.

Antonsson T, Gudbergsson G. 2006. Áhrif loftslagsbreytinga á fiskistofna í ferskvatni. Rit Fraedathings landbúnadarins 2006: 95-101.

Árnason B, Theodórsson P, Björnsson S, Saemundsson K. 1967. Hengill, a high temperature thermal area in Iceland. Bulletin volcanologique 33: 245-260.

Becker CD. 1973. Development of Simulium (Psilozia) vittatum Zett. (Diptera: Simuliidae) from larvae to adults at thermal increments from 17.0 to 27.0 C. American Midland Naturalist 89(1): 246-251,

Berg MB. 1995. Larval food and feeding behaviour. In: Armitage PD, Cranston PS and Pinder LCV (eds). The Chironomidae: Biology and ecology of non-biting midges. Chapman \& Hall. pp 136-168.

Brittain JE. 1978. Semivoltinism in mountain populations of Nemurella pictetii (Plecoptera). Oikos 30(1): 1-6.

Butler MG. 1982. A 7-year life-cycle for two Chironomus species in arctic Alaskan tundra ponds (Diptera: Chironomidae). Canadian Journal of Zoology 60(1): 58-70.

CAFF. 2010. Arctic Biodiversity Trends 2010 - Selected indicators of change. Akureyri, Iceland: CAFF International Secretariat.

Christensen JB. 2006. Biologisk struktur i vandløb med varierende geothermisk indflydelse. Implikationer af global warming. Msc thesis. Silkeborg, Denmark: University of Aarhus. p 69.

Christensen JH, Hewitson B, Busuioc A, Chen A, Gao X, Held I, Jones R, Kolli RK, Kwon W-T, Laprise R, Magaña Rueda V, Mearns L, Menéndez CG, Räisänen J, Rinke A, Sarr A, Whetton P. 2007. Regional Climate Projections. In: Solomon S, Qin D, Manning M, Chen Z, Marquis M, Averyt KB, Tignor M and Miller HL (eds). Climate Change 2007: The Physical Science Basis. Contribution of Working Group I to the Fourth Assessment Report of the Intergovernmental Panel on Climate Change Cambridge, United Kingdom and New York, NY, USA. Cambridge University Press.

Cranston PS. 1982. A key to the larvae of British Orthocladiinae (Chironomidae). Freshwater Biological Association, scientific publication no. 45. $152 \mathrm{p}$.

D’Alba L, Monaghan P, Nager RG. 2010. Advances in laying date and increasing population size suggest positive responses to climate change in Common Eiders Somateria mollissima in Iceland. The International Journal of Avian Science 152(1): 19-28.

Daly HV. 1985. Insect morphometrics. Annual Review of Entomology 30: 415-438.
Einarsson Á, Gardarsson A, Gíslason GM, Gudbergsson G. 2006. Populations of ducks and trout of the River Laxá, Iceland, in relation to variation in food resources. Hydrobiologia 567: 183194.

Elliott JM. 1987. Temperature-induced changes in the life-cycle of Leuctra nigra (Plecoptera: Leuctridae) from a Lake District stream. Freshwater Biology 18(1): 177-184.

Friberg N, Dybkjaer JB, Olafsson JS, Gislason GM, Larsen SE, Lauridsen TL. 2009. Relationships between structure and function in streams contrasting in temperature. Freshwater Biology 54(10): 2051-2068.

Frouz J, Ali A, Lobinske RJ. 2002. Influence of temperature on developmental rate, wing length, and larval head capsule size of pestiferous midge Chironomus crassicaudatus (Diptera: Chironomidae). Journal of Economic Entomology 95(4): 699705.

Galka BE, Brust RA. 1987. The effect of temperature and photoperiod on the induction of larval diapause in the mosquito Aedes togoi (Theobald) (Diptera: Culicidae). Canadian Journal of Zoology-Revue Canadienne De Zoologie 65(9): 2262-2265.

Gardarsson A. 1979. Waterfowl populations of Lake Mývatn and recent changes in numbers and food habits. Oikos 32(1-2): 250270.

Gardarsson A, Einarsson Á, Jónsson E, Gíslason GM, Ingvarsson HR, Ólafsson JS, Hrafnsdóttir T. 2000. Stofnvísitölur mýflugna í Mývatnssveit í tuttugu ár, 1977 - 1996 (Population indices of chironomid and simuliid Diptera at Lake Myvatn over a period of 20 years, 1977-1996). Fjölrit 5. Skútustadir vid Mývatn: Náttúrurannsóknarstöd vid Mývatn. p 121.

Gislason GM, Hrafnsdottir T, Gardarsson A. 1995. Flight period of midges (Chironomidae and Simuliidae) in the River Laxa, N-Iceland. In: Cranston PS (ed.). Chironomids: From Genes to Ecosystems. CSIRO Publications. pp 133-140.

Gíslason GM. 1992. The life cycle of Limnephilus griseus (L.) (Trichoptera, Limnephilidae) in temporary rock pools in northern England. Proceedings of the 7th International Symposium on Trichoptera: 171-175.

Gudjónsson G, Egilsson K, Skarphédinsson KH. 2005. Gródur og fuglar á Hengilssvaedi og Hellisheiði. The Icelandic Institute of Natural History. p 49.

Gudmundsdottir R, Gislason GM, Palsson S, Olafsson JS, Schomacker A, Friberg N, Woodward G, Hannesdottir ER, Moss B. 2011. Effects of temperature regime on primary production in Icelandic geothermal streams. Aquatic botany 95: 283-291.

Gunnarsson B, Ásgeirsson T. 2006. Sandraekja finnst við Ísland. Náttúrufraedingurinn 74: 39-42.

Gunnarsson TG. 2009. Fuglar og loftlagsbreytingar (A short review of climate change impacts on bird populations). Bliki 30: 61-64.

Hodkinson ID, Coulson SJ, Webb NR, Block W, Strathdee AT, Bale JS, Worland MR. 1996. Temperature and the biomass of flying midges (Diptera: Chironomidae) in the high Arctic. Oikos 75(2): 241-248.

Hrafnsdottir T. 2005. Diptera 2 (Chironomidae). The zoology of Iceland III(48b): 1-169.

Høye TT, Post E, Meltofte H, Schmidt NM, Forchhammer MC. 2007. Rapid advancement of spring in the High Arctic. Current Biology 17(12): R449-R451.

Ingólfsson A, Ólafsson ÓP, Morritt D. 2007. Reproduction and 
life-cycle of the beachflea (Orchestia gammarellus (Pallas) (Crustacea: Amphipoda) at thermal and non-thermal sites in the intertidal of Iceland: how important is temperature? Marine Biology 150(6): 1333-1343.

Jonsson E, Gardarsson A, Gislason GM. 1986. A new window trap used in the assessment of the flight periods of Chironomidae and Simuliidae (Diptera). Freshwater Biology 16(6): 711-719.

Jónsson G, Pálsson J, Jóhannsson M. 2001. Ný fisktegund, flundra, Platichthys flesus (Linnaeus, 1758) veidist á Íslandsmidum (English summary: New fish species, founder, Platichthys flesus (Linnaeus, 1758) fished in Icelandic grounds). Náttúrufraedingurinn 70(2-3): 83-89.

Lam PKS, Calow P. 1989. Intraspecific life-history variation in Lymnaea peregra (Gastropoda, Pulmonata) I. Field-study. The Journal of Animal Ecology 58(2): 571-588.

Langton PH. 1991. A Key to Pupal Exuviae of West Palaearctic Chironomidae. 5 Kylebeg Av., Mountsandel, Cleraine Co. Londonderry, Northern Ireland. Privately published by P.H. Langton. 386 p.

Libungan LA, Gíslason GM, Thórdarsson T. 2009. Folafluga nýtt skordýr á Íslandi (English summary: The Marsh Cranefly (Tipula paludosa Meigen 1830) recorded in Iceland, with notes on its ecology). Náttúrufraedingurinn 77 (3-4): 107-112.

Lindegaard C. 1992. Zoobenthos ecology of Thingvallavatn: vertical distribution, abundance, population dynamics and production. Oikos 64(1-2): 257-304.

Maasri A, Fayolle S, Franquet E. 2010. Algal foraging by a rheophilic chironomid (Eukiefferiella claripennis Lundbeck) extensively encountered in high nutrient enriched streams. Fundamental and Applied Limnology 177(2): 151-159.

Mackey AP. 1977. Growth and development of larval Chironomidae. Oikos 28(2-3): 270-275.

Malmquist HJ, Antonsson, Ingvarsson HR, Ingimarsson F, Árnason F. 2009. Salmonid fish and warming of shallow Lake Elliðavatn in Southwest Iceland. Verhandlungen des Internationalen Verein Limnologie 30(7): 1127-1132.

McCauley VJ. 1974. Instar differentiation in larval Chironomidae (Diptera). The Canadian Entomologist 106(2): 179-200.

Menzel A, Sparks TH, Estrella N, Koch E, Aasa A, Ahas R, AlmKübler K, Bissolli P, Braslavská O, Briede A, Chmielewski FM, Crepinsek Z, Curnel Y, Dahl A, Defila C, Donnelly A, Filella Y, Jatcza K, Måge F, Mestre A, Nordli Ø, Peñuelas J, Pirinen P, Remišová V, Scheifinger H, Striz M, Susnik A, Van Vliet AJH, Wielgolaski FE, Zach S, Zust A. 2006. European phenological response to climate change matches the warming pattern. Global Change Biology 12(10): 1969-1976.

Nolte U, Hoffmann T. 1992. Fast life in cold water: Diamesa incallida (Chironomidae). Ecography 15(1): 25-30.

Oliver DR. 1968. Adaptations of arctic Chironomidae. Annales Zoologici Fennici 5: 111-118.

Oliver DR. 1971. Life history of the Chironomidae. Annual Review of Entomology 16: 211-230.

Ólafsson JS, Ingimundardóttir GV, Hansen I, Sigurdardóttir SG. 2010. Smádýralíf í afrennslisvatni frá háhitasvaedunum við Kröflu, Ölkelduháls og í Middal í Henglinum (English summary: Macroinvertebrate assemblages in effluent water from the high temperature geothermal areas of Krafla, Ölkelduháls and Middalur in Hengill, Iceland). Keldnaholt, 112 Reykjavík, Iceland: Institute of Freshwater Fisheries. p 64.
Pinder LCV. 1986. Biology of freshwater Chironomidae. Annual Review of Entomology 31: 1-23.

Rasmussen JJ, Baattrup-Pedersen A, Riis T, Friberg N. 2011. Stream ecosystem properties and processes along a temperature gradient. Aquatic Ecology 45(2): 231-242.

Resh VH, Rosenberg DM. 2010. Recent trends in life-history research on benthic macroinvertebrates. Journal of the North American Benthological Society 29(1): 207-219.

Reynolds SK, Benke AC. 2005. Temperature-dependent growth rates of larval midges (Diptera: Chironomidae) from a southeastern U.S. stream. Hydrobiologia 544: 69-75.

Schmid PE. 1993. A key to the larval Chironomidae and their instars from Austrian Danube region streams and rivers. Part 1: Diamesinae, Prodiamesinae and Orthocladiinae. Wien. Federal Institute for Water Quality of the Ministry of Agriculture and Forestry. 514 p.

Solomon S, Qin D, Manning M, Alley RB, Berntsen T, Bindoff NL, Chen Z, Chidthaisong A, Gregory JM, Hegerl GC, Heimann M, Hewitson B, Hoskins BJ, Joos F, Jouzel J, Kattsov V, Lohmann U, Matsuno T, Molina M, Nicholls N, Overpeck J, Raga G, Ramaswamy V, Ren J, Rusticucci M, Somerville R, Stocker TF, Whetton P, Wood RA, Wratt D. 2007. Technical Summary. In: Solomon S, Qin D, Manning M, Chen Z, Marquis M, Averyt KB, Tignor M and Miller HL (eds). Climate Change 2007: The Physical Science Basis. Contribution of Working Group I to the Fourth Assessment Report of the Intergovernmental Panel on Climate Change. Cambridge, United Kingdom and New York, NY, USA. Cambridge University Press.

Stefansdottir L, Solmundsson J, Marteinsdottir G, Kristinsson K, Jonasson JP. 2010. Groundfish species diversity and assemblage structure in Icelandic waters during recent years of warming. Fisheries Oceanography 19(1): 42-62.

Stefánsson SM. 2005. Mýsamfélög og lífsferlar rykmýs í dragám á Íslandi. MSc thesis. Institute of biology. Reykjavík: University of Iceland. p 70 .

Steingrímsson SO, Gíslason GM. 2002. Body size, diet and growth of landlocked brown trout, Salmo trutta, in the subarctic River Laxá, North-East Iceland. Environmental Biology of Fishes 63(4): 417-426.

Stenström A, Jónsdóttir IS. 2006. Effects of simulated climate change on phenology and life history traits in Carex bigelowii. Nordic Journal of Botany 24(3): 355-371.

Sweeney BW. 1984. Factors influencing life-history patterns of aquatic insects. In: Resh VH and Rosenberg DM (eds). The ecology of aquatic insects. New York. Praeger publishers. pp 56-100.

Taylor F. 1981. Ecology and evolution of physiological time in insects. The American Naturalist 117(1): 1-23.

Thórarinsdóttir GG, Ólafsson MF, Kristjánsson TÖ. 2007. Lostaetur landnemi (Delicious settler). Náttúrufraedingurinn 75: 34-40.

Tokeshi M. 1995. Life cycles and population dynamics. In: Armitage PD, Cranston PS and Pinder LCV (eds). The Chironomidae: Biology and ecology of non-biting midges. London. Chapman \& Hall. pp 225-268

Walshe B. 1948. The oxygen requirements and thermal resistance of chironomid larvae from flowing and from still waters. The Journal of Experimental Biology 25: 35-44.

Wiederholm T. 1983. Chironomidae of the Holarctic region. Keys 
and Diagnoses. Part 1. Larvae. Entomologica Scandinavica Suppl. $449 \mathrm{p}$.

Wiederholm T. 1986. Chironomidae of the Holarctic region. Keys and Diagnoses. Part 2. Pupae. Entomologica Scandinavica Suppl. $482 \mathrm{p}$.

Wilson RS, Ruse LP. 2005. A Guide to the Identification of Genera of Chironomid Pupal Exuviae Occurring in Britain and Ireland (Including Common Genera from Northern Europe) and their Use in Monitoring Lotic and Lentic Fresh Waters. The Ferry House, Far Sawrey, Ambleside, Cumbria, U.K. Freshwater Biological Association, special publication no. $13.176 \mathrm{p}$.

Woodward G, Dybkjær JB, Ólafsson JS, Gíslason GM, Hannesdóttir ER, Friberg N. 2010. Sentinel systems on the razor's edge: effects of warming on Arctic geothermal stream ecosystems. Global Change Biology 16(7): 1979-1991.

Wöll C. 2008. Treeline of mountain birch (Betula pubescens Ehrh.) in Iceland and its relationship to temperature. Department of Forestry: Technical University Dresden. p 125. 